\title{
THE USE OF GADOLINIUM ORTHOVANADATE NANOPARTICLES FOR THE CORRECTION OF REPRODUCTIVE ABILITY IN BOARS UNDER OXIDATIVE STRESS
}

V. I. KOSHEVOY ${ }^{1}$, PhD Student, Department of Veterinary Reproductology https://orcid.org/0000-0003-2938-2762

S. V. NAUMENKO ${ }^{1}$, PhD, Associate Professor,

Department of Veterinary Reproductology https://orcid.org/0000-0002-7340-5186

V. K. KLOCHKOV², PhD, Senior Research Fellow, Department of Nanostructured Materials https://orcid.org/0000-0002-8080-1195

S. L. YEFIMOVA², Doctor of Physical and Mathematical Sciences, Professor, Department of Nanostructured Materials https://orcid.org/0000-0003-2092-1950 ${ }^{1}$ Kharkiv State Zooveterinary Academy, 1 Academic st., Mala Danylivka 62341 Kharkiv Oblast, Ukraine ${ }^{2}$ Institute of Scintillation Materials of the National Academy of Sciences of Ukraine, 60 Nauky ave., Kharkiv 61072, Ukraine

E-mail: vsevolod_koshevoy@yahoo.com

\begin{abstract}
The search for effective and safe means for correcting male hypofertility is an urgent problem of modern reproductology. Researchers have proved the possibility of the use of nanoparticles based on oxides of rare-earth elements for the treatment of disorders of male reproductive function. We investigated the effectiveness of the use of gadolinium orthovanadate nanoparticles activated by europium, the size of which was $25 \times 8 \mathrm{~nm}$ in the dose of $0.0125 \mathrm{mg}$ per $\mathrm{kg}$ of live weight to correct reproductive ability decrease in boars under oxidative stress. After 14 days of hydrosol nanoparticles administration, we experimentally established the dynamics of the content of oxidative stress markers and stable metabolites in the nitrogen oxide cycle, and also determined the changes in sperm quality indicators. Thus, conjugated dienes concentration in the blood serum of boars on the 15th day tended to decrease, and on the 30th day of the study was lower by $9.4 \%$ compared with the group of animals before administration. At the same time, the amount of thiobarbituric acid reactive substances decreased on the 15 th day of the study by $24.7 \%$, and the 30th day - by $48.2 \%$, which indicates the normalization of oxidative processes in males. We noted positive changes in the system
\end{abstract}

${ }^{1}$ scientific supervisor - PhD, Associate Professor S. V. Naumenko 
of the nitrogen oxide cycle, the content of stable metabolites on the 15th day was lower by $25.2 \%$ than in animals before administration and on the 30th day - by $42.6 \%$. At the same time, we observed an improvement in the boar sperm quality, especially motility and the number of motile sperm in the ejaculate increased by 42.9 and $57.1 \%$ on the 60 th day of the study and by $95.2 \%$ and 1.48 times on the 90th day, respectively. In this case, the volume of ejaculate, sperm concentration, and sperm content with morphological anomalies with the introduction of nanoparticles normalized and almost reached the values of the control group. The researchers are interested in further elucidating the effect of correction of reduced reproductive ability in boars under oxidative stress with gadolinium orthovanadate nanoparticles on the hormonal background and the state of enzymatic and non-enzymatic systems of antioxidant protection.

Keywords: sperm quality, prooxidant-antioxidant system, peroxidation, oxidative stress markers, nitrogen oxide cycle, nanomaterials

\section{Introduction}

The main cause of reduced reproductive ability in males (hypofertility) is a negative impact of oxidative stress accompanied by an intensification of the synthesis of reactive oxygen species (ROS), and at the same time, nitrogen (RNS) and sulfur, an accumulation of toxic peroxidation products and reduced antioxidant activity of antioxidant defense system (ADS) (Bisht et al., 2017; Barik et al., 2019; Koshevoy \& Naumenko, 2020; Otasevic et al., 2020).

The problem of research is a significant spread of factors that cause oxidative stress in males and the lack of harmless means for the correction, which would also have pronounced effectiveness and contribute to the rapid improvement of sperm quality (Mayorga-Torres et al., 2016; Agarwal et al., 2018).

\section{Analysis of recent researches and publications}

The main means for the correction of oxidative stress include groups of drugs that directly or indirectly have an antioxidant effect or reduce the intensity of peroxidation processes by eliminating toxic products. The mechanism of action of these drugs depends on the peculiarities of their pharmaceutical composition. Vitamin and mineral drugs make an effect by improving the activity of the non-enzymatic part of ADS. For instance, carotenoids in the body contribute to vitamin A synthesis in the liver and activation of ADS processes, as well as the introduction of tocopherols and ascorbic acid (Domoslawska et al., 2018; Skliarov et al., 2020).

The enzymatic ADS is affected by the introduction of microelements such as zinc and copper. They are a part of one of the main enzymes in the first link of ADS - superoxide dismutase, which acts as a substrate for another powerful enzyme - catalase (Palani, 2018; Scarlata \& O'Flaherty, 2020). Drugs based on succinic acid, which is the main component of Roberts' shunt and has its effect in the nervous system (Zarubina et al., 2012), are characterized by a powerful antioxidant effect. In this case, the significant role of the nitrogen oxide cycle and its metabolites in the functioning of the male reproductive system and the relationship with sperm activation and sperm quality (Liman \& Alan, 2016) were proved. 
A promising direction in the creation of oxidative stress correction is the development of nanomaterials that exhibit redox properties, such as cerium dioxide and vanadates based on rare-earth elements, in particular gadolinium (Koreneva et al., 2016). A positive effect of such nanoparticles on the reproductive function of male rats in the case of reproductive diseases and experimental prostatitis has been proved (Belkina et al., 2017; Karpenko et al., 2020). A peculiar feature of vanadium compound action is the effect on the ADS by increasing the activity of enzymes such as superoxide dismutase, catalase, and, especially, glutathione link - glutathione peroxidase, as indicated in human hepatocytes in vitro (Kim et al., 2012).

The aim of the study is to investigate the effectiveness of the use of gadolinium orthovanadate nanoparticles activated by europium to correct reduced reproductive ability in boars under oxidative stress.

\section{Materials and methods of research}

The research was conducted at the Department of Veterinary Reproductology, Faculty of Veterinary Medicine at Kharkiv State Zooveterinary Academy. The studies were performed on boars kept on a standard diet with free access to water.

Animals in terms of sperm quality and the content of oxidative stress markers - conjugated dienes (CD), as primary of lipid peroxidation products, the final product - thiobarbituric acid reactive substance (TBARS), as well as stable metabolites of the nitrogen oxide $\left(\mathrm{NO}_{\mathrm{x}}\right)$ cycle were divided into two groups. The sperm quality in males of the control group $(n=5)$ met the standards. It was reduced in the experimen- tal group ( $(n=5)$, especially in terms of sperm motility and the number of motile sperm in the ejaculate, while there was an intensification of peroxidation processes by the content of oxidative stress markers in blood serum.

To correct oxidative stress, nanoparticles (NPs) of oxides of rare-earth elements synthesized at the Department of Nanostructured Materials of the Institute of Scintillation Materials at the National Academy of Sciences of Ukraine under the agreement on scientific and practical cooperation (№ 48，22/07/2020) were used. Males of the experimental group were orally administered hydrosol of gadolinium orthovanadate NPs activated by europium, size $25 \times 8 \mathrm{~nm}$ granular form at a dose of $0.0125 \mathrm{mg}$ per $\mathrm{kg}$ of live weight for 14 days. It has been investigated that gadolinium orthovanadate NPs belong to the toxicity class IV - low-toxic compounds, which allows use in biomedical studies (Koreneva et al., 2016).

The effectiveness of the developed method for the correction was evaluated by the changes in sperm quality and the content of oxidative stress markers in blood serum of males. Blood serum samples were taken on the 1st, 15th, and 30th days. Sperm quality was assessed on the 1st, 60th, and 90th day of the study. Macroscopic (volume) and microscopic (sperm motility and number of motile sperm in the ejaculate, concentration, percentage of sperm content with morphological abnormalities) sperm quality indicators were evaluated according to common methods (Yablonskyi, 2005). The content of oxidative stress markers in blood serum was estimated using spectrophotometric methods in order to determine the concentrations of CD and TBARS (Vlizlo et al., 2012) and $\mathrm{NO}_{\mathrm{x}}$ (Golikov, 2004).

All manipulations with animals were carried out in accordance with the Europe- 
an Convention for the protection and vertebrate animals used for experimental and other scientific purposes (2006) and General ethical principles of animal experiments adopted by the First National Congress on Bioethics (Kyiv, Ukraine, 2001).

All digital data obtained during the study were processed statistically using Microsoft EXCEL. The Student's criterion was used to determine the probability of differences between mean values.

\section{Results of the research and their discussion}

Determination of the content of oxidative stress markers in biological fluids - blood, serum or plasma, sperm or sperm plasma allows obtaining objective information concerning the intensity of biological oxidation processes in males. This becomes important taking into account the seasonality of these processes and possible lack of adequate response from antioxidant defense system, especially in case of combined action of negative factors - inducers of peroxidation. Analyz-

$\mathrm{CD}, \mu \mathrm{mol} / \mathrm{L}$
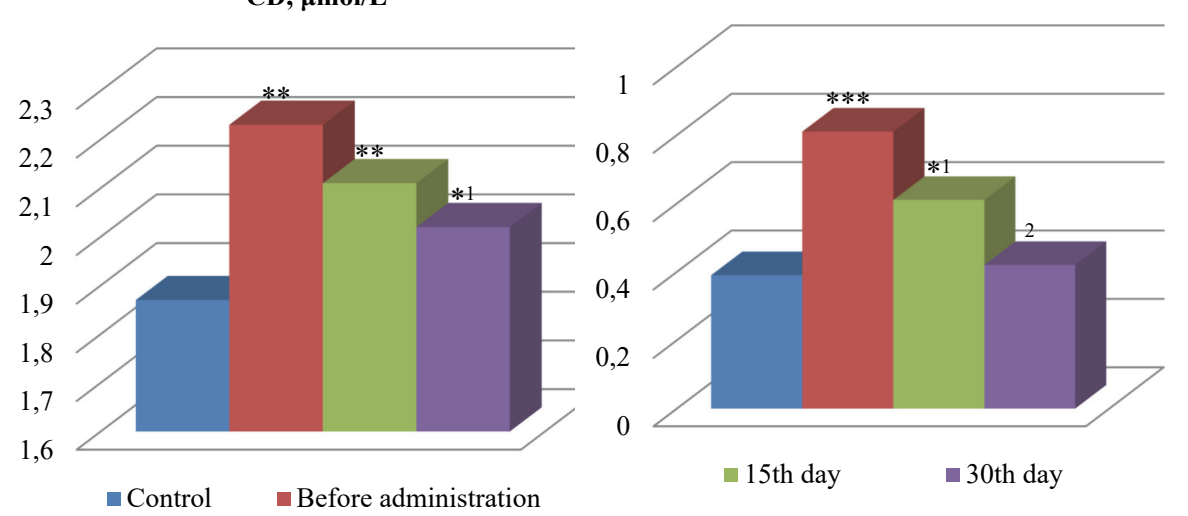

Fig. 1. The intensity of peroxidation processes in blood serum of boars during the correction by gadolinium orthovanadate nanoparticles $(M \pm \mathbf{m}, \mathbf{n}=\mathbf{5})$

Notes. $* \mathrm{P}<0.05 ; * * \mathrm{P}<0.01 ; * * * \mathrm{P}<0.001-$ statistically significant changes in relation to the control group; ${ }^{1} \mathrm{P}<0,05 ;{ }^{2} \mathrm{P}<0,001$ - statistically significant changes in relation to the group of animals before administration.

ing the results of biochemical studies, we determined the state of oxidative stress in males of the experimental group (Fig. 1) the content of primary LPO products $-\mathrm{CD}$ was higher than the control rate by $19.3 \%$ $(\mathrm{P}<0.01)$. There was also an increase in the concentration of TBARS in blood serum by 1.07 times $(\mathrm{P}<0.001)$, which is the final product of LPO.

The number of $\mathrm{NO}_{\mathrm{x}}$ was also significantly increased (Fig. 2$)-$ by $83.6 \%(\mathrm{P}<$ $0.001)$ compared with the control group. The increase of these indicators shows an increase in the intensity of peroxidation processes and the presence of nitrosative damage in boars, which is the main cause of reduced reproductive ability and is consistent with previously obtained data (Koshevoy \& Naumenko, 2020).

We conducted a chronic experiment in order to establish the effectiveness of the use of NPs oxides of rare-earth elements as a safe pharmacological agent to correct reduced reproductive ability in boars under oxidative stress with pronounced redox and sperm-modulating activities.

TBARS, $\mu \mathrm{mol} / \mathrm{L}$ 
$\mathrm{NO}_{\mathrm{x}}, \mu \mathrm{mol} / \mathrm{L}$

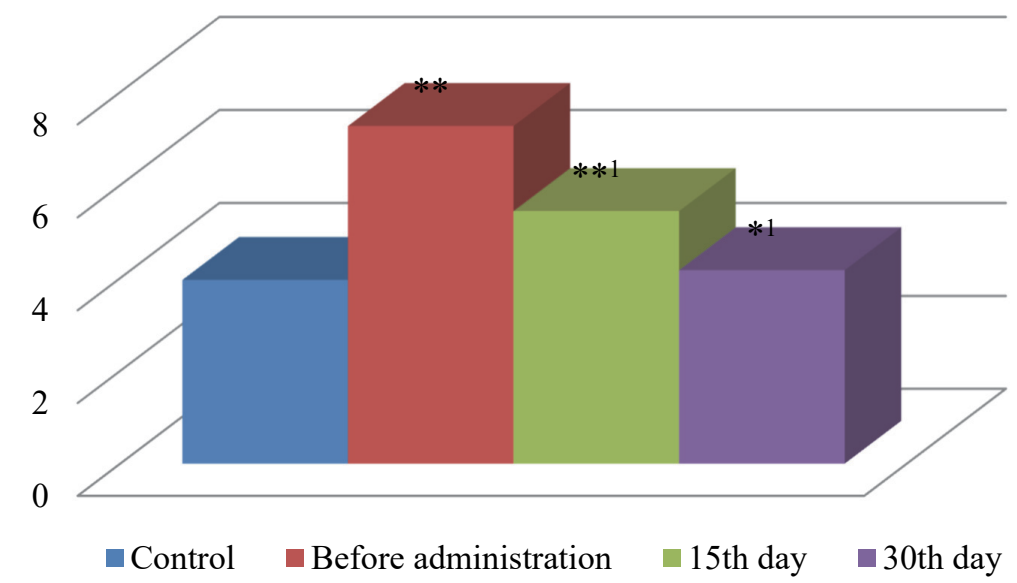

Fig. 2. The content of stable metabolites of the nitrogen oxide cycle in blood serum of boars after the correction by gadolinium orthovanadate nanoparticles $(\mathbf{M} \pm \mathbf{m}, \mathbf{n}=\mathbf{5})$

Notes. $* \mathrm{P}<0.05$; ** $\mathrm{P}<0.001$ - statistically significant changes in relation to the control group; ${ }^{1} \mathrm{P}<0.001-$ statistically significant changes in relation to the group of animals before administration.

Thus, after the correction by gadolinium orthovanadate NPs activated by europium, a decrease in the intensity of peroxidation processes was observed in the blood serum of boars. At the same time, the studied indicators had a positive dynamics of changes on the 15th day of the study: the amount of CD tended to decrease and was 5.4\% less than before administration, and the concentration of TBARS was lower by $24.7 \%(\mathrm{P}<0.05)$. The amount of $\mathrm{NO}_{\mathrm{x}}$ also decreased by $25.2 \%(\mathrm{P}<0.001)$. This indicates that the administration of NPs has a positive effect on the dynamics of peroxidation.

Restoration of prooxidant balance, which almost reached the indicators of the control group was observed in the blood serum on the 30th day of the study. The CD content was reduced by 9.4\% $(\mathrm{P}<0.05)$, the TBARS concentration was lower than before administration by $48.2 \%$ ( $\mathrm{P}<0.001)$. This indicates a decrease in the intensity of
LPO processes and the presence of a prolonged effect of the introduction of NPs hydrosol. Similar changes were observed in the nitrogen oxide cycle - its amount was lower by $42.6 \%$ $(\mathrm{P}<0.001)$. The obtained data confirm the effectiveness of the use of gadolinium orthovanadate NPs for the correction of oxidative stress in boars.

Reduced reproductive ability in boars under oxidative stress is determined by the deterioration of sperm quality. It was found that males of the experimental group had significantly reduced sperm motility (by $51.2 \%$, $\mathrm{P}<0.001)$ and the number of motile sperm in the ejaculate (by $63.2 \%$, $\mathrm{P}<0.001)$. There was also a decrease in ejaculate volume by $17.2 \%(\mathrm{P}<0.001)$ and sperm concentration by $10.5 \%$ $(\mathrm{P}<0.01)$, while the content of sperm with morphological abnormalities was higher by $24 \%(\mathrm{P}<0.001)$ compared with the indicators of the control group. 
The presence of a correlation between LPO intensity and indicators of male sperm quality has been proved by many authors. In particular, our studies have confirmed a significant decrease in motility and the number of motile sperm in boar ejaculate. Analyzing the obtained data, we can conclude that the influence of the accumulation of ROS and RNS in boars, i.e. oxidative stress leads to deterioration of spermogram indicators and requires correction. This coincides with the opinion of most authors of the cited literature. The correction of oxidative stress in boars in case of reduced reproductive ability by gadolinium orthovanadate NPs has a positive effect on the dynamics of spermiogenesis, which was established by assessing the sperm quality in animals of the experimental group (Table 1).

Thus, on the 60th day of the study, the sperm motility indicator was higher than in animals before the administration of hydrosol NPs by $42.9 \%$ $(\mathrm{P}<0.01)$, while the number of motile sperm in the ejaculatewas higher by $57.1 \%$ ( $\mathrm{P}<0.01)$. In general, the quality of the obtained sperm was higher than be- fore the administration of NPs - ejaculate volume by $5.8 \%(\mathrm{P}<0.05)$, sperm concentration - by $5.9 \%(\mathrm{P}<0.05)$, and sperm content with morphological abnormalities tended to decrease. This is likely to ensure the cost-effectiveness of this method of correction.

Evaluating the effectiveness of the oxidative stress correction by gadolinium orthovanadate NPs it was noted that on the 90th day of the study the quality indicators of ejaculate almost reached the values of the control in males. Sperm motility indicators are particularly sensitive to the action of oxidative stress and the number of motile sperm in the ejaculate increased by $95.2 \%(\mathrm{P}<0.001)$ and 1.48 times $(\mathrm{P}<0.001)$ in relation to the group of animals before administration. A positive effect of nanoparticles was observed on the dynamics of ejaculate volume, which on the 90th day of the study was higher by $15.1 \%(\mathrm{P}<0.001)$, sperm concentration, which was higher by $11.8 \%(\mathrm{P}<0.01)$. The sperm content with morphological anomalies decreased by $18.3 \%(\mathrm{P}<0.01)$.

The effectiveness of the introduction of gadolinium orthovanadate NPs can

\section{Indicators of boar sperm quality after the correction by gadolinium orthovanadate nanoparticles $(M \pm m, n=5)$}

\begin{tabular}{|c|c|c|c|c|c|}
\hline \multirow{3}{*}{ № } & \multirow{3}{*}{ Indicator } & \multicolumn{4}{|c|}{ Animal group } \\
\hline & & \multirow[b]{2}{*}{ control } & \multicolumn{3}{|c|}{ experiment } \\
\hline & & & $\begin{array}{c}\text { before } \\
\text { administration }\end{array}$ & day 60 & day 90 \\
\hline 1 & Ejaculate volume, $\mathrm{mL}$ & $209.5 \pm 3.2$ & $173.5 \pm 3.0 * * *$ & $183.6 \pm 2.9 * * * 1$ & $199.7 \pm 2.5 * 3$ \\
\hline 2 & Sperm concentration, billion $/ \mathrm{mL}$ & $0.19 \pm 0.003$ & $0.17 \pm 0.003^{* *}$ & $0.18 \pm 0.002 * 1$ & $0.19 \pm 0.0032$ \\
\hline 3 & Mobility, scores & $8.6 \pm 0.3$ & $4.2 \pm 0.4 * * *$ & $6.0 \pm 0.3 * * * 2$ & $8.2 \pm 0.4$ \\
\hline 4 & $\begin{array}{l}\text { The number of motile sperm } \\
\text { in the ejaculate, billion }\end{array}$ & $34.2 \pm 1.02$ & $12.6 \pm 1.32 * * *$ & $19.8 \pm 1.19 * * * 2$ & $31.3 \pm 1.623$ \\
\hline 5 & $\begin{array}{l}\text { The content of sperm with } \\
\text { morphological abnormalities, \% }\end{array}$ & $15.4 \pm 0.6$ & $19.1 \pm 0.4^{* * *}$ & $18.2 \pm 0.4^{* *}$ & $15.6 \pm 0.62$ \\
\hline
\end{tabular}

Notes. $* \mathrm{P}<0.05 ; * * \mathrm{P}<0.01 ; * * * \mathrm{P}<0.001-$ statistically significant changes in relation to the control group; ${ }^{1} \mathrm{P}<0.05 ;{ }^{2} \mathrm{P}<0.01 ;{ }^{3} \mathrm{P}<0.001-$ statistically significant changes in relation to the group of animals before administration. 
be explained by the increased activity of these compounds in the transition to the nanoform, as they do not manifest such properties in the form of industrial pharmaceutical compositions, which are known today. The results of the study of boar spermogram after oxidative stress correction prove the presence of sperm-modeling action of NPs based on oxides of rare-earth elements. It can be recommended for practical implementation and development of methods for correction of hypofertility of different genesis in males of different species.

\section{Conclusions and future perspectives}

The efficiency of the developed correction method for the reduced reproductive ability in boars under oxidative stress by gadolinium orthovanadate NPs is proved:

1. Positive dynamics of changes in the intensity of peroxidation processes with the introduction of hydrosol NPs of gadolinium orthovanadate were observed, namely: the concentration of conjugated dienes in blood serum of boars, which on the 15 th day tended to decrease, and on the 30th day of the study was less by $9.4 \%$ compared with the indicators before administration.

2. Normalization of oxidative processes in males was confirmed by a decrease in the amount of the final product of LPO - thiobarbituric acid reactive substance on the 15 th day of the study - by $24.7 \%$, and on the 30 th day - by $48.2 \%$.

3. A decrease in the activity of the Nitrogen oxide cycle was determined. The content of stable metabolites in the blood serum of boars on the 15 th day was lower than in animals before administration by $25.2 \%$, and on the
30 th day - by $42.6 \%$. Such changes indicate the action of nanoparticles as scavengers of oxygen radicals.

4. The method of correction had a significant effect on sperm quality indicators, especially on sperm motility and the number of motile sperm in the ejaculate, which increased by 42.9 and $57.1 \%$ on the 60 th day and by $95.2 \%$ and 1.48 times on the 90 th day of the study, respectively.

5. Ejaculate volume, sperm concentration, and sperm content with morphological anomalies after the administration of nanoparticles normalized and almost reached the values of the control group.

Perspectives for further research are to elucidate the effect of correction of reduced reproductive ability in boars under oxidative stress by gadolinium orthovanadate NP on the hormonal background indicators and the state of enzymatic and non-enzymatic systems of antioxidant defense, as well as to determine additional spermogram parameters.

\section{References}

Agarwal, A., Rana, M., Qui, E., AlBunni, H., Bui, A. D., \& Henkel, R. (2018). Role of oxidative stress, infection and inflammation in male infertility. Andrologia, 50(11:e13126). doi: 10.1111/and.13126

Barik, G., Chaturvedula, L., \& Bobby, Z. (2019). Role of oxidative stress and antioxidants in male infertility: An interventional study. Journal of human reproductive sciences, 12(3), 204. doi: 10.4103/jhrs.jhrs_135_18

Belkina, I. O., Smolenko, N. P., Klochkov, V. K., Malukin, Yu. V., Chistyakova, E. E., Karpenko, N. A., \& Karachentsev, Yu. I. (2017). The assessment of gadolinium orthovanadate nanoparticles value for neonatally-induced reproductive disease in male rats. International journal of physiology and pathophys- 
iology, 8(4), 299-307. doi: 10.1615/IntJPhysPathophys.v8.i4.20

Bisht, S., Faiq, M., Tolahunase, M., \& Dada, R. (2017). Oxidative stress and male infertility. Nature reviews urology, 14(8), 470-485. doi: 10.1038/nrurol.2017.69

Domoslawska, A., Zdunczyk, S., Franczyk, M., Kankofer, M., \& Janowski, T. (2018). Selenium and vitamin $\mathrm{E}$ supplementation enhances the antioxidant status of spermatozoa and improves semen quality in male dogs with lowered fertility. Andrologia, 50(6:e13023). doi: 10.1111/and.13023

Golikov, P. P. (2004). Oksid azota v klinike neotlozhnyh zabolevanij [Nitric oxide in an emergency clinic]. Moskva.

Karpenko, N. O., Korenieva, Ye. M., Chystiakova, E. Ye., Smolienko, N. P., Bielkina, I. O., Kustova, S. P., ... \& Klochkov, V. K. (2020). Doslidzhennia prostatoprotektornoi ta spermomodeliuiuchoi dii nanochastynok na osnovi oksydiv ridkisnozemelnykh elementiv [The studying of the prostateprotective and spermmodulating effects of the nanoparticles based on rare-earth elements oxides]. Problemy endokrynnoi patolohii, 3, 109118. doi: 10.21856/j-PEP.2020.3.14

Kim, A. D., Zhang, R., Kang, K. A., You, H. J., Kang, K. G., \& Hyun, J. W. (2011). Jeju ground water containing vanadium enhances antioxidant systems in human liver cells. Biological trace element research, 147(1-3), 16-24. doi: 10.1007/s12011-011-9277-5

Koreneva, E. M., Karpenko, N. A., Smolenko, N. P., Belkina, I. O., Chistyakova, E. Ye., Selyukova, N. Y., Karachentsev, Yu. I., ... \& Kavok, N. S. (2016). Vplyv nanochastynok ortovanadatu hadoliniiu ta dioksydu tseriiu na spermohramu doroslykh samtsiv shchuriv iz neonatalno indukovanymy rozladamy reproduktyvnoi funktsii [The influence of gadolinium orthovanadate and cerium dioxide nanoparticles on spermogram of adult male rats with neonatal induced disorders of reproductive function]. Problemy endokrynnoi patolohii, 1, 48-55.
Koshevoy, V. I., \& Naumenko, S. V. (2020). The impact of oxidative stress in reducing the reproductive capacity of the boar-inseminators. Veterinary science, technologies of animal husbandry and nature management, 5, 246-249. doi: 10.31890/ vttp.2020.05.43

Liman, N., \& Alan, E. (2016). Region-specific localization of NOS isoforms and NADPH-diaphorase activity in the testicular and excurrent duct systems of adult domestic cats (Felis catus). Microscopy research and technique, 79(3), 192-208. doi: 10.1002/jemt.22619

Mayorga-Torres, B. J. M., Camargo, M., Cadavid, A. P., du Plessis, S. S., \& Cardona Maya, W. D. (2016). Are oxidative stress markers associated with unexplained male infertility? Andrologia, 49(5:e12659). doi: 10.1111/and.12659

Otasevic, V., Stancic, A., Korac, A., Jankovic, A., \& Korac, B. (2020). Reactive oxygen, nitrogen, and sulfur species in human male fertility: A crossroad of cellular signaling and pathology. BioFactors, 46(2), 206-219. doi: 10.1002/biof.1535

Palani, A. F. (2018). Effect of serum antioxidant levels on sperm function in infertile male. Middle East fertility society journal, 23(1), 19-22. doi: 10.1016/j.mefs.2017.07.006

Scarlata, E., \& O'Flaherty, C. (2020). Antioxidant enzymes and male fertility: lessons from knockout models. Antioxidants \& redox signaling, 32(8), 569-580. doi: 10.1089/ars.2019.7985

Skliarov, P. M., Fedorenko, S. Y., Naumenko, S. V., Onischenko, O. V., \& Holda, K. O. (2020). Retinol deficiency in animals: etiopathogenesis and consequences. Regulatory mechanisms in biosystems, 11(2), 162-169. doi: 10.15421/022024

Vlizlo, V. V. (2012). Laboratorni metody doslidzhennia u biolohii, tvarynnytstvi ta veterynarnii medytsyni: dovidnyk [Laboratory research methods in biology, animal husbandry and veterinary medicine: handbook]. Lviv: Spolom.

Wright, C., Milne, S., \& Leeson, H. (2014). Sperm DNA damage caused by oxidative stress: modifiable clinical, lifestyle and nutrition- 
al factors in male infertility. Reproductive biomedicine online, 28(6), 684-703. doi: 10.1016/j.rbmo.2014.02.004

Yablonskyi, V. A. (2005). Biotekhnolohiia vidtvorennia tvaryn [Biotechnology of animal reproduction]. Kyiv.
Zarubina, I. V., Lukk, M. V., \& Shabanov, P. D. (2012). Antihypoxic and antioxidant effects of exogenous succinic acid and aminothiol succinate-containing antihypoxants. Bulletin of experimental biology and medicine, 153(3), 336-339. doi: 10.1007/s10517-012-1709-5

\section{В. І. Кошевой, С. В. Науменко, В. К. Клочков, С. Л. Єфімова (2021). ВИКОРИ- СТАННЯ НАНОЧАСТИНОК ГАДОЛІНІЮ ОРТОВАНАДАТУ ДЛЯ КОРЕКЦІЇ РЕПРО- ДУКТИВНОї ЗДАТНОСТІ КНУРІВ ЗА ОКСИДАТИВНОГО СТРЕСУ. Ukrainian Journal of Veterinary Sciences, 12(2): 74-82, https://doi.org/10.31548/ujvs2021.02.008}

Анотація. Пошук ефективних і безпечних засобів корекції гіпофертильності самців $є$ актуальною проблемою сучасної репродуктології. Дослідниками доведена можливість застосування наночастинок на основі оксидів рідкісноземельних елементів для лікування розладів чоловічої репродуктивної функції. Нами досліджено есрективність використання наночастинок гадолінію ортованадату активованих європієм розміром 25×8 нм зерноподібної форми в дозі 0,0125 мг на кг живої маси для корекції зниження репродуктивної здатності кнурів за оксидативного стресу. Експериментально, після 14-добового введення гідрозолю наночастинок нами встановлена динаміка вмісту маркерів оксидативного стресу і стабільних метаболітів циклу Нітрогену оксиду, а також визначено зміни показників якості сперми. Так, концентрація дієнових кон'югатів у сироватці крові кнурів на 15-ту добу мала тенденцію до зниження, а на 30-ту добу дослідження була вірогідно меншою на 9,4\% показників групи тварин до введення. Водночас, кількість кінцевого продукту ліпопероксидації - малонового діальдегіду вірогідно зменшувалася на 15-ту добу дослідження на 24,7\%, а на 30 добу - на 48,2\%, що свідчить про нормалізацію окисних процесів в організмі самців. Позитивні зміни відзначено в системі циклу Нітрогену оксиду, вміст стабільних метаболітів якого на 15 добу був вірогідно меншим показників тварин до введення на 25,2\%, а на 30-ту добу - на 42,6\%. Одночасно відмічали покращення показників якості сперми кнурів, особливо рухливості й кількості рухливих сперміїв у еякуляті, які підвищилися відповідно на 42,9 і 57,1\% на 30-ту добу та на 95,2\% і в 1,48 раза на 60-ту добу дослідження. Водночас, об'єм еякуляту, концентрація сперміїв і вміст сперміїв із морфологічними аномаліями за введення наночастинок нормалізувалися й майже досягли значень групи контролю. Інтерес дослідників полягає у подальшому з'ясуванні впливу корекції зниження репродуктивної здатності кнурів за оксидативного стресу наночастинками гадолінію ортованадату на показники гормонального фону та стан ензиматичної й неензиматичної систем антиоксидантного захисту.

Ключові слова: якість сперми, прооксидантно-антиоксидантна система, пероксидація, маркери оксидативного стресу, цикл нітрогену оксиду, наноматеріали 